\title{
A influência do discurso filosófico de Nietzsche na reestruturação do conceito de eclesiologia na contemporaneidade
} The influence of Nietzsche's philosophical discourse on the restructuring of the concept of ecclesiology in contemporary times

\author{
SAULO PAMATOa
}

\section{Resumo}

Enquanto sustenta um relativismo radical, a pós-modernidade descontrói os conceitos fundamentais das visões tradicionais, rejeitando por completo uma visão única e correta de mundo. Se a concepção medieval lançou seu foco em Deus e a modernidade na realidade externa ao indivíduo, surge na contemporaneidade a centralidade na perspectiva humana líquida, fluida e oscilante. Com isso, não obstante o testemunho bíblico forneça fundamento irrefutável acerca do propósito de Cristo, surge no seio do evangelicalismo moderno um movimento que, embora envolto numa nova roupagem, visa trazer ao debate a validade da doutrina da eclesiologia, oferecendo juízo concernente a sua legitimidade. Cabe à Teologia Cristã em seu estudo crítico compreender a história e desenvolvimento das percepções lógicofilosóficas a fim de tornar relevante o conceito de igreja como instituição divina também no cenário atual.

Palavras-chave: Eclesiologia. Pós-modernidade. Teologia. Cosmovisão. Evangelicalismo.

\section{Abstract}

While maintaining a radical relativism, postmodernity disrupts the fundamental concepts of traditional visions, rejecting completely a single and correct view of the world. If the medieval conception has focused on God and modernity on the external reality of the subject, there arises in the contemporary the centrality in the liquid, fluid and oscillating human perspective. Thus,

a Universidade do Sul de Santa Catarina (UNISUL), Tubarão, SC, Brasil. Doutor, e-mail: s.pamato@hotmail.com 
although biblical testimony provides an irrefutable basis for Christ's purpose, a movement emerges within modern evangelicalism that, although enveloped in a new garb, seeks to bring to debate the validity of the doctrine of ecclesiology, offering judgment concerning its legitimacy. It is up to Christian Theology in its critical study to understand the history and development of logical-philosophical perceptions in order to make the concept of the church as a divine institution relevant in the present scenario as well.

Keywords: Ecclesiology. Postmodernity. Theology. Worldview. Evangelicalism.

\section{Introdução}

A estrutura tradicional do pensamento cristão, mais precisamente a partir do período da reforma protestante do século XVI, tem assistido o surgimento de inúmeros movimentos filosófico-teológicos que, em suma, buscam ressignificar aquilo que, até então, era incontestável no testemunho bíblico. Com a expansão da filosofia para além dos limites da teologia, a razão, gradativamente, passa a ser a faculdade capaz de deliberar acerca do homem em toda sua integralidade.

Não obstante a crítica da religião tenha se avultado no final do século XVIII e início do século XIX com Kant, Hegel e Marx, o centro das reflexões filosóficas vai eclodir na segunda metade do século XIX com Friedrich Nietzsche (ZILLES, 2008, p. 40).

Embora Nietzsche seja frequentemente lembrado pela fórmula "Deus está morto", considerando a transcendência da fé no divino um absurdo e, nas palavras do autor, um "mundo puramente fictício" (NIETZSCHE, 2016a, §15, p. 27), tal visão exclusivista impede a compreensão de sua reflexão acerca da finitude humana, bem como de sua influência, mesmo que de maneira indireta, na contemporaneidade religiosa.

É nesse universo que surge em Nietzsche o conceito de "espírito livre". Desenvolvido naquela que seria uma de suas principais obras (NIETZSCHE, 2015, §24, p. 45), o filósofo alemão apresenta-o, em síntese, como retrato daquele que se libertou da necessidade de fidelidade a uma determinada posição ideológica, tornando-se crítico das interpretações existentes, sendo capaz de examiná-las de maneira decisiva, reformando-as quando necessário.

Enquanto o impacto de tais pensamentos não assumia grandes proporções no contexto religioso, pouco valor se deu aos primeiros resultados. Contudo, com a divulgação dos últimos dados levantados pelo Instituto Brasileiro de Geografia e 
Estatística (IBGE, 2010), a tradição protestante presenciava o surgimento de uma comunidade até então inusitada, os "evangélicos nominais", popularmente identificados pelo título de "desigrejados". Estes, que no final do século XX, perfaziam menos de $1 \%$ do universo religioso, apresentavam um crescimento superior a 780\%, atingindo números superiores a 9 milhões de pessoas.

Alcançando o propósito central, a abordagem privilegiou a análise de fontes bibliográficas dentro de uma perspectiva filosófico-teológica que buscou identificar o impacto da reflexão de Friedrich Nietzsche e seus desdobramentos sobre o modus operandi do macrocosmo do evangelicalismo moderno. Para tal, abordaremos a gênese do ambiente da filosofia moderna e sua crítica à religião, passando pela compreensão da influência, ainda que indireta, da pós-modernidade sobre a cosmovisão cristã, culminando na concepção de eclesiologia segundo as Escrituras. Não obstante, vale ressaltar que, com isso, não se intenta deduzir que o domínio intelectual do pensamento filosófico de Nietzsche foi a força motriz que fomentou este crescimento, contudo a racionalidade filosófica pode conduzir o ser humano no questionamento da importância, estado e significação do transcendente.

\section{Um novo ambiente}

O retorno às ideias de Aristóteles, o surgimento das universidades e a dedicação das ordens mendicantes à erudição foram o estímulo necessário ao despertar intelectual no período conhecido como escolasticismo. Despertada de seus devaneios medievais e reivindicando autoridade em favor da razão, as declarações de René Descartes (1596-1650), tais como "cogito, ergo sum", traduzida por "penso, logo existo" — inauguravam uma nova era (STRATHERN, 1997, p. 7).

Nesse contexto, o desenvolvimento do pensamento filosófico passa a nutrir o protestantismo liberal do século XIX. Num cenário em que a religião fora removida da dimensão especulativa e o cristianismo circunscrito pela razão, o uso da filosofia não mais fornece pressupostos em favor da revelação cristã, mas intensifica a controvérsia em torno de sua validade (MONDIN, 1980, p. 8).

Desde então, a secularização do cristianismo de Hegel, a crítica do teísmo de Schopenhauer e o discurso de Feuerbach acerca da hipostatização do homem incitavam o despertar de uma fria e ruidosa filosofia ocidental que provocaria, no despertar do jovem Nietzsche, a completa supressão da teologia. 


\section{A filosofia de Nietzsche e a crítica à religião}

Nessa altura, Nietzsche já se decidira - "Deus está morto". Como atestado no terceiro livro do escrito "A gaia ciência":

Novos combates. - Depois que Buda morreu, por muitos séculos as pessoas ainda mostravam sua sombra em uma caverna - uma sombra imensa e horrível. Deus está morto: mas do jeito que são as pessoas, talvez ainda mostrem sua sombra em cavernas, durante milênios. - E nós - nós teremos de derrotar sua sombra! (NIETZSCHE, 2016b, §108, p. 193).

Contudo, a problemática levantada pelo filósofo no desenvolvimento de sua crítica ao universo da cultura ocidental, à tradição filosófica e, principalmente, ao cristianismo, não pode moldar uma cosmovisão que o relegue à um cenário ateísta. Isto posto, é possível perceber que Nietzsche não segue o caminho dialético de Hegel que, seria a "deserção de Deus do mundo das coisas e, em particular, do mundo dos homens", considerando a morte de Deus uma sexta-feira santa especulativa, mas limita-se a constatar a incoerência do divino na cultura de seu tempo, sendo, primeiramente, uma crítica à moral e aos valores cristãos.

O louco. - Já ouviram falar daquele louco que acendeu uma lanterna numa manhã muito clara, correu para o mercado e começou a gritar sem parar: "Estou procurando Deus! Estou procurando Deus!" - Como havia muitas pessoas por ali que não acreditavam em Deus, acabou provocando muitas gargalhadas. "Será que alguém o perdeu?", perguntou um deles. "Será que Ele se perdeu, como uma criança?", disse o outro. "Ou está escondido?" "Está com medo de nós?" "Embarcou em algum navio?" "Emigrou" Assim, elas ficaram gritando e rindo, numa grande confusão. O louco saltou no meio delas e lançou-lhes olhares penetrantes. "Para onde foi Deus?", gritou ele, "eu o direi a vocês! Nós O matamos! - vocês e eu! Todos nós somos seus assassinos! [...] Ainda não escutamos o barulho dos coveiros que enterraram Deus? Não sentimos ainda o cheiro da deterioração de Deus? Os deuses também deterioram! Deus está morto! Deus permanece morto! E nós O matamos! [...] Nunca houve um ato maior - e por causa desse ato, quem nascer depois de nós, pertencerá a uma história superior, maior de que toda a história foi até hoje! (NIETZSCHE, 2016b, §125, p. 212).

À vista disso, surge em Nietzsche o retrato do homem que desfere golpes a todo passado que a tradição metafísica tem consagrado. Diante da alegação, a morte de um Deus que assume a personificação da moralidade é o atestado de fracasso dos costumes, tradições e valores humanos adquiridos a priori. Não existe mais um valor supremo em relação ao qual mensurar todos os demais valores. 
Nessa perspectiva, o prejuízo causado pela condição de rebaixamento e submissão do homem diante do transcendente, permitiu à religião estabelecer um sistema que sacrifica o homem a partir de um projeto moral subjetivo que se legitima em Deus, exigindo fé e obediência radicais. Por conseguinte, percebe-se aqui o término de uma época caracterizada pelo modelo platônico de pensamento no que tange à realidade fora da realidade sensível, popularmente conhecido por "teoria das ideias", inaugurando um tempo marcado pelo cisma entre um mundo divino com sua verdade no modelo religioso judaico-cristão e um mundo humano (LIMA, 2015, p. 30).

Desse modo, do interior do "velho homem" formado nos "velhos paradigmas" precisa renascer um "novo homem", expresso no conceito de Übermensch (NIETZSCHE, 2016b, §III, p. 24), traduzido por "super-homem", "capaz de pensar o eterno retorno de todas as coisas com um júbilo e uma alegria não acessível a nenhum ser simplesmente humano, demasiado humano" (LEFRANC, 2005, p. 310).

Ao anunciar o "réquiem divino" (NIETZSCHE, 2016b, §125, p.214), Nietzsche aponta para uma transvaloração dos valores na tentativa de superar a religião da decadência que construiu sua projeção de mundo ideal em detrimento do mundo real (SOUZA, 2007, p. 101).

Em Nietzsche, todavia, a inauguração da pós-modernidade não deve ser compreendida como superação da modernidade, pois seria como retroceder à uma postura moderna. Consequentemente, a própria verdade torna-se um valor dissolvido. Assim, a medida que a humanidade perdeu o seu referencial absoluto, o que restou foi o nada. Em suma, se Deus está morto, então não resta mais nada a que o homem possa se manter e em direção a que ele possa se direcionar (HEIDEGGER, 2003, p. 479).

\section{O desenvolvimento do conceito de espírito livre}

Em seus escritos médios e tardios, Friedrich Nietzsche passa a desenvolver um retrato complexo e fragmentado de um tipo de caráter marcado pela liberdade que, embora não se manifeste de maneira tradicional, como liberdade política ou democrática, é compreensível "para os poucos" e "muito fortes" (NIETZSCHE, 2015, §29, p. 53). Ansiando por libertar-se dos dogmas da sociedade, tais homens vivem 
de modo distinto do que se esperaria com base nas opiniões que predominam em seu tempo (NIETZSCHE, 2008, §225, p .95).

Atendendo sob o nome de "espírito livre" e descrito como exceção à cultura e crítico, estes percebem que não há fatos eternos, tampouco verdades absolutas, mas que todas as crenças comumente aceitas devem, impiedosamente, ser chamadas a prestar contas e levadas a julgamento (NIETZSCHE, 2015, §33, p. 59). Na perspectiva de Nietzsche, o subjetivismo, a rejeição aos paradigmas culturais e de autoridade governamental, bem como a nutrição do sentimento de "forasteiro" frente a cultura normal são relevantes atributos que caracterizam a figura do espírito livre.

À vista disso, é possível compreender o que Nietzsche pressupõe ao utilizarse do termo "liberdade" no contexto do espírito livre. Para o filósofo, o espírito livre é aquele que se libertou da necessidade de fidelidade a uma determinada posição ideológica, tornando-se crítico das interpretações existentes, demonstrando coragem tamanha que o permita examinar sua própria posição, reformando-a se necessário (NIETZSCHE, 2015, §41, p. 67). Em suma, o espírito "livre" não é um indivíduo que procura reajustar-se ao sistema de valorização, mas encontrar seu próprio sistema de avaliação, firmado na pluralidade de perspectivas e na luta contra a vontade do "rebanho" de tentar arrastá-lo para baixo em suas profundezas.

Por conseguinte, o estímulo por trás do espírito livre, segundo Nietzsche, é a vontade de verdade, traduzida como a necessidade primária responsável por seu autodomínio sobre a vontade, sua separação dos laços com a comunidade e sua aceitação da responsabilidade. Desse modo, a vontade de verdade levaria tais homens superiores a questionar, assumindo como intuito a necessidade de desmantelar as verdades absolutas sustentadas pela tradição comum (MULLIN, 2000, p. 392).

\section{0 religioso sob o fundamento nietzschiano}

Não obstante o pensamento religioso e sua busca de um fundamento rumo à verdade tenha enfrentado forte oposição nesse novo mundo que emergia, como afirmou o sociólogo Joaquim Costa (2009, p. 7), "a religião é coisa religiosa: ressuscita a cada certidão de óbito que lhe passam". Contudo, se por um lado a 
religião não deixa de ser o que ela é, por outro já não é o que ela foi (PORTELLA, 2008, p. 34).

Erigida sob o vácuo dos fundamentos que se perderam, a pós-modernidade surge como consequência da frustração da modernidade. $O$ fracasso no ideal de felicidade do iluminismo e a incapacidade da razão científica de reencantar o homem em desespero instauravam um período marcado pela incredulidade nas metanarrativas, abandonando crenças em visões totalizantes da história que prescreviam regras de conduta política e ética para toda a humanidade (LIMA, 2015, p. 74).

O pós-modernismo desembarcou na filosofia em fins dos anos 60 , com uma mensagem demolidora na mochila: a desconstrução do discurso filosófico ocidental, da maneira como o ocidente pensa e age. Discurso é fala, é o dito. Desconstruir o discurso não é destruí-lo, nem mostrar como foi construído, mas pôr a nu o não-dito por trás do que foi dito, buscar o silenciado (reprimido) sob o que foi falado.

A pós-modernidade é a modernidade que atinge a maioridade, a modernidade olhando-se a distância e não de dentro, fazendo um inventário completo de ganhos e perdas, psicanalizando-se, descobrindo as intenções que jamais explicitara, descobrindo que elas são mutuamente incongruentes e se cancelam. A pós-modernidade é a modernidade chegando a um acordo com a sua própria impossibilidade, uma modernidade que se auto monitora, que conscientemente descarta o que outrora fazia inconscientemente (BAUMAN, 1999, p. 288).

Contudo, embora existindo num universo diluído, a visão religiosa do mundo não ganhou contornos que a relegassem à uma condição insignificante. Se por um lado a religião não é mais a pedra angular sob a qual se estrutura a vida social em toda sua integralidade, é inegável que sua influência não sucumbiu diante do "eclipse do sagrado" proposto pela teoria da secularização.

No individualismo operante na condição pós-moderna, o pertencimento institucional torna-se dispensável. Na ausência de filiações tradicionais, o estabelecimento de uma religião que dispõe seus bens simbólicos num mercado religioso garante autonomia individual e liberdade do sujeito (PIERUCCI, 2004, p. 19). 
Até então conhecida como retorno à ortodoxia e ao dogma num contexto institucionalizado, a religião na contemporaneidade é antropocêntrica, expressa no self. Em outras palavras, é aquilo que concede sentido à vida de indivíduos em suas subjetividades, não dependente de formulação ou fidelidade institucional (PORTELLA, 2008, p. 34).

Logo, não se formula a hipótese de que o homem pós-moderno tenha se tornado menos religioso. Abandonamos uma religião para encontrar religiosidade (DEBRAY, 2005, p. 309).

\section{A desigrejação do cristianismo}

Dos decepcionados com a liderança aos críticos do modus operandi, dos oprimidos em nome de Deus aos nascidos em meio a heresia do neopentecostalismo, a institucionalização da Igreja, por muitos, tem sido advogada como a grande causa da deserção eclesiástica. Estes, ao considerar o desvirtuamento em sua natureza, essência, proposta relacional comunitária e de missão, tem enfatizado o distanciamento entre a práxis e os fundamentos lançados por Cristo e seus apóstolos (BOMILCAR, 2012, p. 15).

Adotando a expressão "niilismo eclesiástico", o escritor Émile Léonard (1963) inaugura o termo que classificaria os cristãos defensores de um cristianismo completamente destituído em forma e estrutura. Embora o utilize num contexto distinto daquele empregado por Nietzsche, Léonard observa no darbismo do século XIX, aquele que seria o embrião do atual movimento dos "desigrejados".

O desejável não é a união formal dos corpos professantes externos: na verdade, o surpreendente é que haja protestantes que desejem isso. Longe de ser algo benéfico, imagino que seria totalmente impossível um corpo assim ser reconhecido como a Igreja de Deus. Seria uma contrapartida da unidade católica; perderíamos a vida da Igreja e o poder da Palavra, e a unidade da vida espiritual ficaria completamente eliminada (MILLER, 2005, p. 19).

De fato, embora a tradição cristã já apontasse para aquele que seria o desdobrar destes movimentos, tal preocupação só passou a ocupar o debate religioso após a divulgação do censo realizado pelo Instituto Brasileiro de Geografia e Estatística (IBGE, 2010). Desse modo, estabelecia-se em território brasileiro aquilo que, há pouco, era utopia ao protestantismo. 
Descrentes resolutos quanto às reais possibilidades de ser Igreja, o movimento de desigrejação do cristianismo, contudo, não é amorfo ou injustificado. Dentre uma série de princípios evocados, tem-se destacado que: (1) Cristo não deixou qualquer forma de Igreja organizada e institucional; (2) afastando-se dos ensinos de Jesus, os cristãos dos primeiros séculos organizaram-se como instituição estruturada, criando ofícios para substituir os carismas e hierarquias para proteger e defender a própria instituição. Organizaram-se de tal maneira que deixaram Deus de fora. Por fim, com a influência da filosofia grega sobre a teologia e a oficialização do cristianismo por Constantino no século IV, a Igreja institucionalizada corrompeuse completamente; (3) não obstante a Reforma ter se levantado contra tal corrupção, os protestantes acabaram por cair no mesmo problema, criando denominações organizadas, sistemas interligados de hierarquia e processos de manutenção do sistema, tais como disciplina e exclusão de dissidentes, confissões de fé e catecismos que, por sua vez, engessaram a mensagem de Jesus e impediram o livre pensamento teológico; (4) a Igreja verdadeira não possui templos, cultos regulares, tesouraria, hierarquia, clero, propriedades, entre outros, visto que, conforme o ensino de Jesus, onde estiverem dois ou três crentes nele, ali está a Igreja; (5) a Igreja como instituição humana, não raramente, tem falhado e sucumbido diante de erros, pecados e escândalos, prestando um desserviço ao Evangelho. Assim, é necessário sair dela a fim de que possamos encontrar a Deus (LOPES, 2010).

Em sua obra "Os sem-Igreja", Nelson Bomilcar (2012, p. 23) descreve em sete classes aqueles que seriam os subgrupos que compõe os desigrejados. Para o autor, encontram-se (1) aqueles que não possuem assumidamente qualquer vínculo institucional com comunidades ou denominações, (2) pessoas que se desencantaram com a instituição formal religiosa e preferiram se manter distantes, tornando-se, por vezes, apenas usuários ou participantes de temas de interesse, (3) indivíduos que estão, de certo modo, arraigados na Igreja institucional, servindose dela com motivações diversas, no entanto, vivem relacionamentos superficiais ou quase nulos no que tange à experiência comunitária, (4) aqueles que se decidiram recolher em pequenos grupos informais, recusando qualquer formatação organizacional, (5) crentes, outrora vinculados à congregações locais, decepcionados relacional ou institucionalmente, (6) pessoas que se professam cristãs e acompanham mensagens e reflexões via internet, mas carecem de 
conexões e balizamentos, permanecendo como observadores, (7) classe daqueles que não passaram por uma real experiência de conversão, expressão de mudança de mente no conceito de "metanoia", não entendendo, discernindo ou aceitando o Evangelho de Cristo, seu Reino e missão.

\section{Fragmentos da ruptura institucional na história da igreja}

Apesar de a crítica incisiva ao modelo institucional das igrejas tenha se notabilizado na última década, tal frustração não é inédita na história da tradição cristã. No decorrer de mais de dois mil anos, inúmeros indivíduos e grupos denunciaram aquilo que seria um completo descaminho dos ensinos de Cristo e da doutrina dos apóstolos, buscando regressar a um padrão simples de vida cristã, completamente desprovido de ênfase litúrgica, ordenação e burocratização (CAMPOS, 2017, p. 87).

Fundamentados em novos argumentos, embora mascarados em uma nova roupagem, a observação do sábio Salomão de que "nada há de novo debaixo do sol" (Ec 1,9) talvez expresse, com excelência, as proposições de tais revolucionários.

\section{O montanismo}

Influente movimento iniciado na região da Ásia Menor, mais precisamente no território da Frígia, atual Turquia, por volta do ano 172 d.C (MATOS, 2005, p.124).

Acreditando ser um profeta enviado por Deus para reformar a igreja mediante o ascetismo, a prática da glossolalia e a continuidade das revelações proféticas, Montano, um sacerdote pagão que se convertera ao cristianismo, rejeitava a crescente fé na autoridade especial dos bispos, estimados pelo cristianismo oficial por serem herdeiros dos apóstolos e guardiões da sã doutrina (OLSON, 1999, p. 30).

Num sentido mais amplo, Montano e suas profetizas percebiam as igrejas cristãs como extremamente formais, completamente dependentes de uma liderança humana, assim como ausentes do direcionamento do Espírito Santo, julgando-as como espiritualmente mortas. Desse modo, enquanto atraia seguidores, Montano profetizava acerca do iminente retorno de Cristo à Frígia e 
denunciava o cristianismo institucionalizado, principalmente na figura dos bispos e líderes da igreja (OLSON, 1999, p. 30).

Aqui, percebe-se o antagonismo que Montano criara entre a autoridade do clero e a liberdade do Espírito Santo, culminando em sua contestação acerca das Escrituras Sagradas como único meio reconhecido de ouvir a voz de Deus. Embora precedidos por movimentos como o ebionismo, o marcionismo e o gnosticismo, uma vez excomungados da Igreja Cristã, os montanistas tornaram-se o primeiro caso de rompimento com o segmento da igreja oficial, visto seu questionamento eclesiológico (CAMPOS, 2017, p. 91).

Embora extremada, este movimento exerceu influência sobre vultos do cristianismo ortodoxo, dentre eles Zeferino, bispo de Roma, e Tertuliano de Cartago (WALKER, 2006, p. 87; COMPENHAUSEN, 2010, p. 199).

Os pais do deserto

Rememorado pela conversão de Constantino, os famosos concílios de Niceia e Constantinopla, bem como pela oficialização do cânon das Escrituras, o século IV foi marcado por importantes acontecimentos na história do cristianismo que pavimentaram sua ortodoxia e organização institucional e litúrgica (CAMPOS, 2017, p. 93).

Contudo, inúmeros líderes da igreja passaram a perceber que a conversão do imperador Constantino em 312 d.C. não significou uma bênção, mas o início de uma grande apostasia (FERREIRA; MYATT, 2007, p. 841). Segundo eles, a consequente eliminação das perseguições aos cristãos foi suficiente para promover um acomodamento. Desde então, muitos recusavam-se dispor ao sofrimento ou martírio, preferindo desfrutar dos benefícios agora concedidos por Roma. Em sua obra "Uma história ilustrada do cristianismo", Justo L. González expõe:

Durante quase trezentos anos, a igreja vivera sob a ameaça constante das perseguições. Todo cristão sabia que era possível que qualquer dia ele fosse levado para o tribunal, onde teria de se defrontar com a terrível escolha entre a apostasia e a morte. Durante os extensos períodos de paz que houve entre os séculos II e III, alguns se esqueceram disso e, quando a perseguição recrudesceu, não puderam resistir-Ihe. Isto, por sua vez, convenceu outros de que a segurança e a vida acomodada eram o principal perigo que os ameaçava, e que esse era muito real durante os períodos de relativa calma. Agora, com a paz da igreja aparentemente assegurada, muitos destes consideravam essa paz uma nova artimanha do maligno. [...] Como testemunhar do Crucificado, daquele que não tinham nem onde 
repousar a cabeça, quando os líderes da igreja têm mansões luxuosas, e quando o sangrento testemunho do martírio já não é possível? Como vencer o maligno, que constantemente nos tenta com as novas honras que a sociedade nos oferece? A resposta de muitos não se fez esperar: fugir da sociedade humana; abandonar tudo; subjugar o corpo e as paixões que dão ocasião à tentação. Assim, ao mesmo tempo em que a igreja se enchia de milhares que pediam o batismo, houve um verdadeiro êxodo de outros milhares que procuravam a santidade na solidão (GONZÁLEZ, 2011, p. 146).

Estes cristãos, insatisfeitos com a carência de vitalidade e espiritualidade e buscando experimentar maior comunhão com Deus e a prática de uma fé desornada, passaram a abandonar o formalismo institucional e a corrupção moral das igrejas cristãs e retiraram-se para o deserto, principalmente do Egito e Síria (CAMPOS, 2017, p. 94; FERREIRA; MYATT, 2007, p. 841).

Em contrapartida, muitos que haviam se dedicado à vida monástica, passaram a estampar um orgulho espiritual, tornando-se vaidosos de seus feitos. Reputando-se como mais dignos e santos do que muitos dos atuais sacerdotes e bispos, os "pais do deserto" deveriam, agora, oferecer julgamento acerca de quais doutrinas seriam verdadeiras e dignas de serem professadas pela cristandade.

Embora não experimentassem o rompimento com a igreja oficial, seu desencantamento com a igreja institucionalizada e, segundo eles, conivente com o Império Romano, marcaram seu movimento de protesto (CAMPOS, 2017, p.95).

O donatismo

A política religiosa do agora convertido ao cristianismo Constantino, não havia agradado a todos os cristãos. Se, por um lado, os monges do deserto retiravam-se a fim de romper seus laços com a igreja, por outro observou-se o surgimento de muitos cristãos que alegavam que o restante da igreja havia se corrompido, restando-lhes o título de verdadeira igreja (GONZÁLEZ, 2011, p. 160).

A causa dos seguidores de Donato da Casa Negra dizia respeito ao tratamento àqueles que haviam apostatado diante das violentas perseguições. Em suma, os donatistas rejeitavam o episcopado de sacerdotes que tinham negado a fé cristã e entregue às autoridades romanas suas cópias das Escrituras a fim de evitar maiores calamidades às suas congregações, recebendo a alcunha de "traditores" (CAMPOS, 2017, p. 97). 
Enquanto muitos traditores foram reconduzidos ao episcopado, retornando ao exercício de suas funções, os donatistas eram rígidos em afirmar que (1) a validade da ordenação dependia da dignidade do bispo, e (2) a dignidade do ministro implicava a validade do sacramento administrado (GONZÁLEZ, 2011, p.161).

Vale ressaltar que o fundamento dos donatistas não se restringiu apenas ao tratamento dado ao traditores. Anteriormente à conversão de Constantino, a igreja em Cartago era formada, predominantemente, por pessoas de classe social baixa que sofriam forte opressão de grupos que mantinham ligações com o Império Romano. Dado a conversão do imperador, indivíduos que compunham tal grupo opressor passaram a congregar com os oprimidos, trazendo consigo toda a tensão já existente no contexto socioeconômico (CAMPOS, 2017, p. 98).

Desse modo, percebe-se que o movimento donatista, embora contenha elementos teológicos em questão, foi nutrido por motivações sociais na tentativa de ruptura com a igreja institucionalizada.

O joaquimismo

Joaquim de Fiore, monge cisterciense e abade na Calábria, localizada no extremo sul da Itália, foi considerado por muitos como o profeta de uma nova era. Em sua obra "O evangelho eterno", fazendo alusão às três pessoas da trindade, Joaquim propôs dividir a história do mundo em três eras, a saber, (1) a do Pai - de Adão até o nascimento de Cristo, (2) a do Filho - abrangendo o período do Novo Testamento e da igreja cristã, e (3) a do Espírito - era iminente e igualitária de liberdade e amor que recebeu o nome de "monástica", uma vez que seria formada por valores comunitários dos mosteiros (WALKER, 2006, p. 373).

Embora considerado mais um poeta e simbolista do que teólogo ou exegeta, a revelação integral do evangelho eterno na era do Espírito tornou-se o argumento daqueles que refutavam o esquema teológico proposto por Joaquim de Fiore. Isto porque, segundo o monge, a plenitude espiritual seria caracterizada por uma igreja despida de materialidade, não clericalizada e hierarquizada, livre de toda sua estrutura orgânica, existindo tão somente espiritualmente (CAMPOS, 2017, p. 110). Como exposto por Delumeau (1997), revelaria uma "nova igreja, livre, espiritual, humilde e silenciosa, casta e virginal como Maria: igreja de contemplativos e caridade". 
Com o nome de "espirituais", aqueles franciscanos começaram a pregar as doutrinas de Joaquim de Fiore. Isto implicava que o papa, o restante da igreja e até mesmo os demais franciscanos eram crentes de um nível inferior, que permaneciam na "era de Cristo", enquanto eles, os espirituais, era a "igreja do Espírito Santo" (GONZÁLEZ, 2011, p. 408).

Desse modo, encontra-se esboçado no movimento joaquimita a ideia da manifestação da igreja monástica, espiritual e perfeita em detrimento de tudo aquilo que a Igreja Católica jamais conseguiu alcançar. Desse modo, a paz viria ao mundo por meio da religião dos monges (DELUMEAU, 1997, p. 43).

Conquanto não tenha rompido oficialmente com a igreja oficial, os pressupostos de Joaquim de Fiore lançaram as bases àqueles que buscavam fundamentação para rejeitar a igreja.

Os anabatistas

Embora a Reforma Protestante do século XVI intentasse ser um movimento contínuo de retorno à Palavra de Deus, de fato, muitos cristãos continuavam insatisfeitos pois viam nela inúmeros descaminhos. Se, por um lado, o luteranismo havia rejeitado somente os aspectos indiscutíveis da Igreja Católica refutados pela Escrituras, por outro as igrejas reformadas foram mais longe e retiveram do catolicismo romano somente aquilo que criam ter autorização das Escrituras (LATOURETTE, 2006, p. 1053).

Por conseguinte, um grupo mais radical emergia. Desejando retornar ao cristianismo primitivo do século I, os anabatistas, assim intitulados por condenarem o pedobatismo e administrarem o segundo batismo a crentes conscientes, passaram a defender uma clara distinção entre a igreja e o Estado, ao passo que rejeitavam a igreja oficial.

Como expresso por Latourette em sua obra "Uma história do cristianismo", muitos deles tendiam a se retirar da sociedade, construindo comunidades próprias que seriam sem contaminação com o mundo ao seu redor, adotando um padrão austero de moralidade e um padrão simples de adoração, alimentação, vestimenta e linguagem.

Contudo, o passar do tempo revelou o surgimento de um movimento hostil e agressivo, duramente perseguido por autoridades religiosas e civis. Na liderança 
de Thomas Müntzer, um dos mais controversos da Reforma Radical, o movimento anabatista realizou duras críticas às autoridades que, em sua leitura, somente teriam legitimidade se obedecessem ao evangelho de Deus distintamente pregado pelo catolicismo e demais movimentos reformados (DREHER, 1996, p. 70 ).

A ruptura com a igreja institucionalizada proposta por Thomas Müntzer excedeu todo e qualquer movimento que ofereceu crítica ao modelo de eclesiologia até então vigente. Isto se deu uma vez que seu posicionamento não se restringiu às expressões católica e protestante, mas ao conjunto das estruturas sociais, políticas e econômicas (CAMPOS, 2017, p. 116).

Os quakers

Fundado por George Fox no século XVII, os quakers ou, como preferiam ser chamados, a Sociedade de Amigos, apontou um cenário de extrema insatisfação. Enquanto as questões doutrinárias e teológicas dominavam as disputas reformadas e filocatólicas, outros grupos flertavam com um cristianismo experimental e menos digmático (CAMPOS, 2017, p. 117).

Nessa tensão, enquanto os anglicanos defendiam uma igreja vinculada à tradição histórica, os puritanos sustentavam a necessidade de uma igreja aos moldes do Novo Testamento. Uma busca por respostas espirituais que pudessem responder aos anseios da alma foi a força motriz por trás deste movimento. $\mathrm{O}$ apelo de George Fox atingira inúmeros outros corações.

Ele sentiu que Cristo poderia falar à "sua condição", seu coração saltou de alegria, e para ele "toda a terra tinha um novo aroma". Ele acreditava que Deus é amor e verdade e que é possível para todos os homens abrirem suas vidas a Ele e também viverem vitoriosamente naquele poder "que está acima de todo mal" e que "está acima de tudo". Ele seguiu e teria outros seguindo a Luz Interior. Renunciou aos juramentos, insistiu na honestidade e no falar a verdade, praticava a simplicidade no vestir, na comida, e na linguagem, se opunha à participação na guerra, protestava contra toda a simulação e formalismo na religião e na adoração, foi pioneiro no cuidado dos insanos, exigiu um tratamento justo para os índios americanos, sustentava que os governos existiam para o benefício do povo como um todo e estão presos pela lei moral. Defendia uma democracia extrema que colocaria os homens e mulheres em um regime de igualdade, permitia que as mulheres pregassem, recusava-se a tirar o chapéu para qualquer homem, usava o pronome singular e se dirigia a pessoas de todas as classes, buscando assim denunciar o privilégio da classe especial, mostrou-se favorável à tolerância religiosa universal, e desejava levar o Evangelho a todos. Completamente destemido, ele foi, muitas vezes, aprisionado por proclamar suas convicções (LATOURETTE, 2006, p. 1113). 
Logo, o movimento dos quakers foi sendo convencido de que não somente o tradicionalismo católico havia se afastado, mas a religião de muitos grupos protestantes estava aquém do padrão estabelecido por Deus. Como expressou González (2011), "se Deus não habita em casas feitas por mãos, por que chamar de igrejas esses edifícios onde as pessoas se reúnem? Fox os chamava então de casas com campanários". Desse modo, não apenas o formalismo religioso passa a ser alvo de suas críticas, mas até mesmo a santa ceia e o batismo, defendendo um posicionamento de que tais sacramentos são sempre interiores e invisíveis (CAMPOS, 2017, p. 119).

Por fim, seu protesto à então religião "formal e vazia" acaba por culminar em incompreensão, crítica e perseguição.

\section{Os darbistas}

O surgimento do darbismo, tal qual os movimentos até então abordados, também se deu pela insatisfação com o estado da atual igreja cristã. O formalismo expresso no clero e a falta daquilo que definiam como "vigor espiritual" foram o impulso necessário à sua eclosão.

Em síntese, os darbistas defendiam um modelo livre e desengajado de igreja, uma vez que a igreja, após a morte dos apóstolos, jamais conseguiu se desvencilhar completamente das tradições humanas. Movimentos que os antecederam, tais como a reforma e o puritanismo, embora intentassem, foram incapazes de prover uma eclesiologia à luz do Novo Testamento (MILLER, 2005, p.7).

Tendo em vista que oferecer uma forma concreta de organização eclesiástica à igreja invisível era invenção humana, o darbismo reafirmava a necessidade do fim do clericalismo e da institucionalização da igreja. Desse modo, permanecer nesse formalismo seria a completa negação prática do significado de igreja (CAMPOS, 2017, p. 122).

É interessante perceber o paralelo que John Nelson Darby, grande defensor das ideias do movimento, faz entre a estrutura externa do então atual sistema religioso vigente e a segunda vinda de Cristo. Para ele, conforme aponta Miller (2005), era impensável permanecer nesses lugares marcados pela apostasia enquanto o cristão se prepara para se reencontrar com o Senhor. 
A saída deles, como você pode imaginar, causou um tumulto de grandes proporções, e suscitou muita oposição. Muitas relações de amizade foram rompidas; muitos estranháveis laços de afeto foram destruídos; muitos sacrifícios tiveram de ser feitos; muitas dores e provações foram enfrentadas; e tantas perseguições, infâmias e vitupérios tiveram de ser suportados (MILLER, 2005, p.24).

Seu futuro foi cercado de desconfiança, uma vez que não possuíam organização, ordem clerical, confissão de fé, tampouco ministros ordenados. Estampando forte crítica ao denominacionalismo das igrejas cristãs, os darbistas continuavam pregando uma deserção institucional como forma de honrar o ensino das Escrituras acerca da natureza da igreja (CAMPOS, 2017, p. 126).

\section{Dietrich Bonhoeffer e o cristocentrismo arreligioso}

Dietrich Bonhoeffer foi um jovem teólogo luterano que envolveu-se ativamente no movimento de resistência contra Hitler durante a Segunda Guerra Mundial. Desde cedo, Bonhoeffer passou a questionar a ideologia nazista e o envolvimento das igrejas com o regime, opondo-se à institucionalização do antisemitismo na Igreja Evangélica Alemã.

Em seu retorno ao território alemão no ano de 1939, Dietrich Bonhoeffer, ao dirigir-se ao seu professor Reinhold Niebuhr, escreve:

Devo passar esse tempo difícil de nossa história nacional com o povo cristão da Alemanha. Não terei o direito de participar da reconstrução da vida cristã na Alemanha após a guerra se não partilhar das provações dessa honra com o meu povo (MATOS, 2005, p. 239).

De fato, o nacionalismo proposto por Hitler havia afetado todas as igrejas alemãs, não somente a católica, mas muitas igrejas protestantes. Então, Bonhoeffer passa a advertir acerca da necessidade do protestantismo não se render diante dos ídolos modernos, mantendo a vitalidade do compromisso cristão. Diante do caos do modelo contemporâneo, a mensagem de Bonhoeffer exigia que a mensagem do cristianismo superasse a dificuldade da sociedade em absorver seu conteúdo (CAMPOS, 2017, p. 130).

A forma do cristocentrismo de Bonhoeffer, ademais, é a-religiosa. Nosso teólogo é uma testemunha comovida da ineficácia da mensagem cristã sobre o homem moderno. Ele considera que tal ineficácia não se deve ao conteúdo, mas à forma: ao modo como a 
mensagem é apresentada, através das categorias religiosas. Estas são ininteligíveis e absurdas para o homem moderno, que se tornou a-religioso. Por isso, Bonhoeffer propõe que se liberte a mensagem bíblica e particularmente o seu núcleo cristocêntrico de tais categorias, reexprimindo-os em termos a-religiosos, que são os únicos que o homem do nosso século pode compreender e aceitar (MONDIN, 1980, p. 166).

Com isso, Bonhoeffer passa a perceber no século XX uma gradativa ausência na busca da ideia acerca do ser supremo, absoluto, não criado. Em suas palavras, a humanidade caminha para uma época completamente arreligiosa, em que nem mesmo aqueles que se dizem religiosos praticam o que dizem (BARCALA, 2010, p. 87).

Embora defendesse que o a priori religioso, ou seja, a predisposição pessoal em tomar consciência de seu eu e da necessidade de relacionar-se com o Sagrado, o teólogo defendia que novos modelos de cristianismo deveriam surgir a fim de que sua mensagem viesse alcançar àqueles que não compreendem ou se adequam ao cristianismo tradicional (BONHOEFFER, 2003, p. 370). É possível que, até então, pouca coisa soe diferente no pensamento de Bonhoeffer, mas um cristianismo não eclesial, sem liturgia, credo ou confissões? Não obstante seu pensamento não tenha promovido o desaparecimento da fé cristã, sua reinterpretação passou a ser vista como arreligiosa. Ainda, é possível identificar no movimento de Bonhoeffer uma clara distinção entre igreja como criada por Jesus Cristo e comunidade religiosa como fenômeno sociológico, bem como a identificação por ele feita de elementos de um cristianismo autêntico em culturas e povos pagãos (BARCALA, 2010, p. 75-7).

Uma vez liberto das expressões religiosas da decadente religiosidade cristã ocidental, seria possível, de acordo com Dietrich Bonhoeffer, desenvolver uma fé que independe da comunidade religiosa e que sabe se dirigir aos arreligiosos (CAMPOS, 2017, p. 132).

\section{Em direção à uma cosmovisão escriturística}

Muito embora a Igreja como organismo e instituição encontre argumento lógico nas Escrituras, o questionamento dos desigrejados não é de todo equivocado. A distorção da autoridade eclesiástica, o sincretismo entre espiritualidade e misticismo e a influência da disposição humana consumista, hedonista e alienada que caracteriza o espírito de época tem provocado profundas 
cicatrizes. Para tal, Ed René Kivitz, em sua obra "Outra espiritualidade: fé, graça e resistência", registra:

\begin{abstract}
A Igreja é, ao mesmo tempo, organismo espiritual e instituição social. O grande desafio é o constante arrancar das ervas daninhas da institucionalização de modo que o organismo espiritual encontra espaço para florescer, frutificar e se alastrar. O que se observa hoje, entretanto, é um movimento contrário, segundo o qual muitas comunidades cristãs caminham a passos largos para a institucionalização - sem falar naquelas que estão com os dois pés fincados no terreno da religiosidade formal (KIVITZ, 2006, p. 85).
\end{abstract}

De fato, a institucionalização excessiva que transformou a Igreja num fim em si mesma e a ausência de uma auto avaliação à luz das Escrituras acerca de nossas práticas, relacionamentos, culto e mensagem, indubitavelmente, podem atestar que as portas do inferno estão prevalecendo (BOMILCAR, 2012, p. 60). Desse modo, torna-se imprescindível que, em essência, toda e qualquer concepção eclesiológica abarque a dupla compreensão que Paulo manifesta como marcas da Igreja, a saber, povo de Deus e corpo de Cristo (ROLOFF, 2005, p. 353).

\title{
A compreensão de igreja no discurso neotestamentário
}

Os escritos neotestamentários apresentam, em unidade e coerência, concepções teológicas precisas acerca da natureza, função e forma da igreja. À vista disso, qualquer afirmação que não considere como discurso normativo a abordagem das Escrituras acerca da eclesiologia carece de fundamentação teórica (ROLOFF, 2005, p. 344).

Contudo, como apresentado por Roloff (2005), não se intenta identificar nas páginas do Novo Testamento uma doutrina uniforme capaz de ser transposta diretamente à nossa situação atual, visto que tal atitude, ao longo da trajetória cristã, somente confirmou concepções determinantes, quanto à natureza e forma da igreja, para a tradição confessional. Assim, o discurso neotestamentário deve ser entendido como uma consideração ampliada que valoriza cada proposta dentro de uma situação histórica específica e não como incorporando alternativas distintas dentre as quais deve-se demonstrar preferência.

Não obstante o fato de toda a autoridade final se baseie em Deus, ele designou Cristo como Mediador e deleita-se em conceder ao homem e suas instituições autoridade para benefício do corpo. Logo, a igreja pode ser 
compreendida, numa dimensão passiva, como comunidade reunida, bem como, ativamente, a mãe de todos os crentes (mater fidelium), sendo ambas obras de Cristo (BAVINCK, 2012, p. 330).

Esse entendimento torna claro o conceito de "corpo de Cristo" tal qual desenvolvido por Paulo em sua carta aos efésios. Tendo o próprio Jesus como cabeça, cabe à igreja espalhar a multiforme sabedoria de Deus que, por meio do evangelho, garante livre acesso a Deus pela fé em Jesus. Desse modo, a igreja tornase o projeto de Deus para anunciar a graças a todos (AZEVEDO, 2011, p. 46).

\begin{abstract}
${ }^{8} \mathrm{~A}$ mim, o mínimo de todos os santos, me foi dada esta graça de anunciar entre os gentios, por meio do evangelho, as riquezas incompreensíveis de Cristo, ${ }^{9} \mathrm{e}$ demonstrar a todos qual seja a comunhão do mistério, que desde os séculos esteve oculto em Deus, que tudo criou por meio de Jesus Cristo; ${ }^{10}$ para que agora, pela igreja, a multiforme sabedoria de Deus seja conhecida dos principados e potestades nos céus, ${ }^{11}$ segundo o eterno propósito que fez em Cristo Jesus nosso Senhor, ${ }^{12}$ no qual temos ousadia e acesso com confiança, pela nossa fé nele. ${ }^{13}$ Portanto, vos peço que não desfaleçais nas minhas tribulações por vós, que são a vossa glória. ${ }^{14}$ Por causa disto me ponho de joelhos perante o Pai de nosso Senhor Jesus Cristo, ${ }^{15}$ do qual toda a família nos céus e na terra toma o nome, ${ }^{16}$ para que, segundo as riquezas da sua glória, vos conceda que sejais corroborados com poder pelo seu Espírito no homem interior; ${ }^{17}$ para que Cristo habite pela fé nos vossos corações; a fim de, estando arraigados e fundados em amor, ${ }^{18}$ poderdes perfeitamente compreender, com todos os santos, qual seja a largura, e o comprimento, e a altura, e a profundidade, ${ }^{19} \mathrm{e}$ conhecer o amor de Cristo, que excede todo o entendimento, para que sejais cheios de toda a plenitude de Deus (Efésios 3.8-19, ACRF).
\end{abstract}

A distinção de igreja como uma associação de crentes em contraposição aos indivíduos crentes permite perceber que, por mais ricamente agraciado com os dons espirituais, jamais um cristão poderá ser ele chamado de "o corpo de Cristo".

Num certo sentido, não igual ao sentido em que a natureza humana de Cristo era o seu corpo durante a sua vida terrena, podemos dizer que a igreja, e não os indivíduos, são agora o corpo dele. E da mesma forma que a habitação do Filho de Deus naquela natureza humana de Cristo capacitou ricamente e exaltou gloriosamente tal natureza com todo tipo de graças espirituais e dons e poderes desconhecidos a qualquer outra pessoa, assim a habitação de Cristo em sua igreja, de uma forma desconhecida aos indivíduos crentes, exalta e capacita a igreja com dons e graças e poderes que nenhum crente individualmente possui. A igreja é "a plenitude daquele que a tudo enche em todas as coisas" (BANNERMAN, 2014, p. 25).

Jesus, como referido no evangelho segundo Mateus, faz referência à igreja como um conjunto de pessoas (Mt 18.17). Ao escrever o livro de Atos dos apóstolos, Lucas sempre se refere à igreja como uma coletividade que se reúne, seja em casas 
ou sinagogas (At 5.11). As epístolas, em sua grande maioria, foram dirigidas a igrejas formadas por várias pessoas. Como expressou Azevedo (2011), "não existe igreja no singular; só no plural. Eu não sou uma igreja; faço parte de uma; somos uma igreja". Constata-se isso ao verificar o significado do termo "igreja" (ekklesía): congregação, assembleia, como traduzido nas edições do Antigo e Novo testamentos:

${ }^{9}$ Subindo eu ao monte a receber as tábuas de pedra, as tábuas da aliança que o Senhor fizera convosco, então fiquei no monte quarenta dias e quarenta noites; pão não comi, e água não bebi; ${ }^{10}$ e o Senhor me deu as duas tábuas de pedra, escritas com o dedo de Deus; e nelas estava escrito conforme a todas aquelas palavras que o Senhor tinha falado convosco no monte, do meio do fogo, no dia da assembleia (Deuteronômio 9.9,10, ACRF, grifo nosso).

Aos moldes do registro veterotestamentário, o Novo Testamento faz menção à congregação no deserto no discurso de Estêvão e, como descrito no livro de Hebreus, a reunião do povo de Deus em torno do seu trono na Jerusalém celestial.

\footnotetext{
${ }^{38}$ Este é o que esteve entre a congregação no deserto, com o anjo que the falava no monte Sinai, e com nossos pais, o qual recebeu as palavras de vida para no-las dar (Atos 7.38, ACRF).

\begin{abstract}
${ }^{18}$ Porque não chegastes ao monte palpável, aceso em fogo, e à escuridão, e às trevas, e à tempestade, ${ }^{19} \mathrm{e}$ ao sonido da trombeta, e à voz das palavras, a qual os que a ouviram pediram que se thes não falasse mais; ${ }^{20}$ porque não podiam suportar o que se thes mandava: Se até um animal tocar o monte será apedrejado ou passado com um dardo. ${ }^{21} \mathrm{E}$ tão terrível era a visão, que Moisés disse: Estou todo assombrado, e tremendo. ${ }^{22}$ Mas chegastes ao monte Sião, e à cidade do Deus vivo, à Jerusalém celestial, e aos muitos milhares de anjos; ${ }^{23}$ à universal assembleia e igreja dos primogênitos, que estão inscritos nos céus, e a Deus, o juiz de todos, e aos espíritos dos justos aperfeiçoados; ${ }^{24} \mathrm{e}$ a Jesus, o Mediador de uma nova aliança, e ao sangue da aspersão, que fala melhor do que o de Abel. ${ }^{25}$ Vede que não rejeiteis ao que fala; porque, se não escaparam aqueles que rejeitaram o que na terra os advertia, muito menos nós, se nos desviarmos daquele que é dos céus (Hebreus 12.18-25, ACRF).
\end{abstract}

Quando em sua atuação terrena, Jesus, de fato, não fundou diretamente a igreja, tampouco preparou a sua fundação para posterior conclusão pelos apóstolos. Todavia, incorre-se num equívoco refutar a noção tradicional de eclesiologia fazendo juízo sob tal perspectiva, uma vez que este pensamento institui o cristianismo como uma nova religião. Como expresso por Ebeling (1963), "Jesus não foi o fundador, mas é o fundamento da igreja". Desse modo, a realidade da 
igreja, antes de tudo, é o efeito de um acontecimento que se inaugura no período pós-pascal do ressurreto (ROLOFF, 2005, p. 62, 347).

\begin{abstract}
Não existe evidência que apoie um relato alternativo, e não importa o que tenha realmente acontecido no dia de Pentecostes, a verdade é que havia uma igreja em Jerusalém alguns poucos anos depois da morte de Jesus. Cabe aos contestadores do relato tradicional da origem da igreja explicar como ela emergiu tão depressa assim. Que probabilidades existiam de um grupo de discípulos desanimados, espalhados e enfraquecidos pelos eventos da crucificação, juntar-se a um homem igual a Pedro e criar um movimento que em breve conquistaria um grande número de seguidores? Por mais extraordinários que sejam os acontecimentos relatados em Atos, qualquer cenário alternativo é ainda mais improvável. Os discípulos de Jesus fugiram ao perceber que, pelo jeito, seu mestre seria morto, e não há motivo para supormos que teriam se reunido novamente alguns dias mais tarde. Eles eram desconhecidos em Jerusalém, e não tinham razões para permanecerem na cidade; na verdade, os evangelhos dizem que eles voltaram para a Galileia, sua terra natal, assim que puderam. Somente algo profundamente recompensador teria vencido o desejo natural deles de retornar à vida normal (como a entendiam), e esse algo foi a ressurreição física de Cristo entre os mortos (BRAY, 2017, p. 47).
\end{abstract}

Desde a ascensão de Jesus, a igreja primitiva reuniu-se em torno da doutrina dos apóstolos, um corpo de argumentos, ensinos, afirmações, testemunhos e tradições acerca de Jesus Cristo (CAMPOS, 2017, p. 147). À vista disso, afirmar-se cristão, em suma, era crer e ser conduzido por verdades fundamentais acerca do Filho de Deus.

Por conseguinte, é inegável não supor que aqueles que detinham credibilidade frente à mensagem messiânica não gozavam de autoridade institucional na igreja primitiva (CERFAUX, 2003, p. 124Ss). Todavia, a institucionalização da comunidade de fé não rompia com a liberdade espiritual e o dinamismo dos primeiros dias da igreja, tampouco impedia que os conflitos fossem resolvidos no seio da igreja de Jerusalém (CAMPOS, 2017, p. 148). Logo, é completamente equivocada e superficial a noção de que a orientação institucional na adoração ou ordem litúrgica, desde que instituída no Novo Testamento, tenha sido danosa ou limitada a atuação do Espírito Santo.

\footnotetext{
${ }^{1}$ Então alguns que tinham descido da Judéia ensinavam assim os irmãos: Se não vos circuncidardes conforme o uso de Moisés, não podeis salvar-vos. ${ }^{2}$ Tendo tido Paulo e Barnabé não pequena discussão e contenda contra eles, resolveu-se que Paulo e Barnabé, e alguns dentre eles, subissem a Jerusalém, aos apóstolos e aos anciãos, sobre aquela questão. ${ }^{3}$ E eles, sendo acompanhados pela igreja, passavam pela Fenícia e por Samaria, contando a conversão dos gentios; e davam grande alegria a todos os irmãos. ${ }^{4} \mathrm{E}$, quando chegaram a Jerusalém, foram recebidos pela igreja e pelos apóstolos e anciãos, e lhes anunciaram quão grandes coisas Deus tinha feito com eles. ${ }^{5}$ Alguns, porém, da seita dos
} 
fariseus, que tinham crido, se levantaram, dizendo que era mister circuncidá-los e mandarIhes que guardassem a lei de Moisés. ${ }^{6}$ Congregaram-se, pois, os apóstolos e os anciãos para considerar este assunto. ${ }^{7} E$, havendo grande contenda, levantou-se Pedro e disse-lhes: Homens irmãos, bem sabeis que já há muito tempo Deus me elegeu dentre nós, para que os gentios ouvissem da minha boca a palavra do evangelho, e cressem. ${ }^{8} \mathrm{E}$ Deus, que conhece os corações, Ihes deu testemunho, dando-lhes o Espírito Santo, assim como também a nós; ${ }^{9}$ e não fez diferença alguma entre eles e nós, purificando os seus corações pela fé. ${ }^{10} \mathrm{Agora}$, pois, por que tentais a Deus, pondo sobre a cerviz dos discípulos um jugo que nem nossos pais nem nós pudemos suportar? ${ }^{11}$ Mas cremos que seremos salvos pela graça do Senhor Jesus Cristo, como eles também. ${ }^{12}$ Então toda a multidão se calou e escutava a Barnabé e a Paulo, que contavam quão grandes sinais e prodígios Deus havia feito por meio deles entre os gentios. ${ }^{13} \mathrm{E}$, havendo-se eles calado, tomou Tiago a palavra, dizendo: Homens irmãos, ouvi-me: ${ }^{14}$ Simão relatou como primeiramente Deus visitou os gentios, para tomar deles um povo para o seu nome. ${ }^{15} \mathrm{E}$ com isto concordam as palavras dos profetas; como está escrito: ${ }^{16}$ Depois disto voltarei, e reedificarei o tabernáculo de Davi, que está caído, levantá-lo-ei das suas ruínas, e tornarei a edificá-lo. ${ }^{17}$ Para que o restante dos homens busque ao Senhor, e todos os gentios, sobre os quais o meu nome é invocado, diz o Senhor, que faz todas estas coisas, ${ }^{18}$ conhecidas são a Deus, desde o princípio do mundo, todas as suas obras. ${ }^{19}$ Por isso julgo que não se deve perturbar aqueles, dentre os gentios, que se convertem a Deus. ${ }^{20}$ Mas escrever-lhes que se abstenham das contaminações dos ídolos, da fornicação, do que é sufocado e do sangue. ${ }^{21}$ Porque Moisés, desde os tempos antigos, tem em cada cidade quem o pregue, e cada sábado é lido nas sinagogas. ${ }^{22}$ Então pareceu bem aos apóstolos e aos anciãos, com toda a igreja, eleger homens dentre eles e enviá-los com Paulo e Barnabé a Antioquia, a saber: Judas, chamado Barsabás, e Silas, homens distintos entre os irmãos. ${ }^{23} \mathrm{E}$ por intermédio deles escreveram o seguinte: Os apóstolos, e os anciãos e os irmãos, aos irmãos dentre os gentios que estão em Antioquia, e Síria e Cilícia, saúde. ${ }^{24}$ Porquanto ouvimos que alguns que saíram dentre nós vos perturbaram com palavras, e transtornaram as vossas almas, dizendo que deveis circuncidar-vos e guardar a lei, não lhes tendo nós dado mandamento, ${ }^{25}$ pareceu-nos bem, reunidos concordemente, eleger alguns homens e enviá-los com os nossos amados Barnabé e Paulo, ${ }^{26}$ homens que já expuseram as suas vidas pelo nome de nosso Senhor Jesus Cristo. ${ }^{27}$ Enviamos, portanto, Judas e Silas, os quais por palavra vos anunciarão também as mesmas coisas. ${ }^{28} \mathrm{Na}$ verdade pareceu bem ao Espírito Santo e a nós, não vos impor mais encargo algum, senão estas coisas necessárias: ${ }^{29}$ Que vos abstenhais das coisas sacrificadas aos ídolos, e do sangue, e da carne sufocada, e da fornicação, das quais coisas bem fazeis se vos guardardes. Bem vos vá (Atos 15.1-29, ACRF).

\section{Ainda, versando acerca da vida em comunidade, o apóstolo Paulo instrui a}

Timóteo com respeito a doutrina, ética, unidade e missão da igreja local:

\footnotetext{
${ }^{14}$ Escrevo-te estas coisas, esperando ir ver-te bem depressa; ${ }^{15}$ mas, se tardar, para que saibas como convém andar na casa de Deus, que é a igreja do Deus vivo, a coluna e firmeza da verdade. ${ }^{16} \mathrm{E}$, sem dúvida alguma, grande é o mistério da piedade: Deus se manifestou em carne, foi justificado no Espírito, visto dos anjos, pregado aos gentios, crido no mundo, recebido acima na glória (1 Timóteo 3.14-16, ACRF).
} 
Em sua obra "Por que amamos a igreja", DeYoung e Kluck (2010) identificam marcas da gradual institucionalização da igreja no Novo Testamento:

\begin{abstract}
Pense naquilo que vemos no Novo Testamento: uma refeição santa celebrada frequentemente (santa ceia); um rito de iniciação que representa àqueles que pertencem à comunidade cristã (batismo); um dia separado (dia do Senhor); [...] o ensino e a leitura do Antigo Testamento (1 Tm 4.13); e epístolas contemporâneas que deveriam ser lidas nas igrejas (1 Ts 5.27). Adicione a esta lista inúmeras doxologias (GI 1.5) e bênçãos (Gl 6.18), [...] o maranata (1 Co 11.26, 16.22) e até mesmo fórmulas litúrgicas futuras a serem repetidas e cantadas pelos santos e anjos no céu (Ap 4, 5, 7, 11, 15, 16, 19 e 22).
\end{abstract}

Portanto, fica evidente que a igreja, embora ainda tivesse os apóstolos, seguia uma padronização doutrinária e litúrgica a fim de manter sua permanente edificação (GOUVEIA, 2006, p. 61).

\title{
A concepção de eclesiologia na tradição cristã
}

Os escritos neotestamentários apresentam, em unidade e coerência, concepções teológicas precisas a respeito da natureza, função e forma da Igreja. Contudo, como apresentado por Roloff (2005, p. 344), não se intenta identificar nas páginas do Novo Testamento uma doutrina uniforme capaz de ser transposta diretamente à nossa situação atual. Assim, o discurso neotestamentário deve ser entendido como uma consideração ampliada que valoriza cada proposta dentro de uma situação histórica específica e não como incorporando alternativas distintas dentre as quais deve-se demonstrar preferência.

A distinção de Igreja como uma associação de crentes em contraposição aos indivíduos crentes permite perceber que, por mais ricamente agraciado com os dons espirituais, jamais um cristão poderá ser ele chamado de "o corpo de Cristo".

Num certo sentido, não igual ao sentido em que a natureza humana de Cristo era o seu corpo durante a sua vida terrena, podemos dizer que a Igreja, e não os indivíduos, são agora o corpo dele. E da mesma forma que a habitação do Filho de Deus naquela natureza humana de Cristo capacitou ricamente e exaltou gloriosamente tal natureza com todo tipo de graças espirituais e dons e poderes desconhecidos a qualquer outra pessoa, assim a habitação de Cristo em sua Igreja, de uma forma desconhecida aos indivíduos crentes, exalta e capacita a Igreja com dons e graças e poderes que nenhum crente individualmente possui. A Igreja é "a plenitude daquele que a tudo enche em todas as coisas" (BANNERMAN, 2014, p. 25). 
A veracidade dessas afirmações pode ser verificada no significado próprio da palavra "Igreja". No contexto escriturístico ou secular, o termo grego ekklesia traz consigo o sentido de assembleia, ajuntamento ou grupo de pessoas. Percebe-se aqui que, de modo algum, a palavra possui natureza essencialmente religiosa. No entanto, a teologia bíblica define em termos essenciais o que qualifica uma assembleia cristã - a reunião do povo de Deus no monte Sinai a fim de ouvir sua Palavra.

Quando em sua atuação terrena, Jesus, de fato, não fundou diretamente a Igreja, tampouco preparou a sua fundação para posterior conclusão pelos apóstolos. Todavia, incorre-se num equívoco refutar a noção tradicional de eclesiologia fazendo juízo sob tal perspectiva, uma vez que este pensamento institui o cristianismo como uma nova religião. Jesus não foi o fundador, mas é o fundamento da Igreja. Desse modo, a realidade da Igreja, antes de tudo, é o efeito de um acontecimento que se inaugura no período pós-pascal do ressurreto (ROLOFF, 2005, p. 62, 347).

\begin{abstract}
Não existe evidência que apoie um relato alternativo, e não importa o que tenha realmente acontecido no dia de Pentecostes, a verdade é que havia uma Igreja em Jerusalém alguns poucos anos depois da morte de Jesus. Cabe aos contestadores do relato tradicional da origem da Igreja explicar como ela emergiu tão depressa assim. Que probabilidades existiam de um grupo de discípulos desanimados, espalhados e enfraquecidos pelos eventos da crucificação, juntar-se a um homem igual a Pedro e criar um movimento que em breve conquistaria um grande número de seguidores? Por mais extraordinários que sejam os acontecimentos relatados em Atos, qualquer cenário alternativo é ainda mais improvável. Os discípulos de Jesus fugiram ao perceber que, pelo jeito, seu mestre seria morto, e não há motivo para supormos que teriam se reunido novamente alguns dias mais tarde. Eles eram desconhecidos em Jerusalém, e não tinham razões para permanecerem na cidade; na verdade, os evangelhos dizem que eles voltaram para a Galileia, sua terra natal, assim que puderam. Somente algo profundamente recompensador teria vencido o desejo natural deles de retornar à vida normal (como a entendiam), e esse algo foi a ressurreição física de Cristo entre os mortos (BRAY, 2017, p. 47).
\end{abstract}

Por conseguinte, é inegável não supor que aqueles que detinham credibilidade frente à mensagem messiânica não gozavam de autoridade institucional na Igreja primitiva. Todavia, a institucionalização da comunidade de fé não rompia com a liberdade espiritual e o dinamismo dos primeiros dias da Igreja, tampouco impedia que os conflitos fossem resolvidos no seio da Igreja de Jerusalém (CAMPOS, 2017, p. 148). 
Pense naquilo que vemos no Novo Testamento: uma refeição santa celebrada frequentemente (santa ceia); um rito de iniciação que representa àqueles que pertencem à comunidade cristã (batismo); um dia separado (dia do Senhor); [...] o ensino e a leitura do Antigo Testamento (1 Tm 4.13); e epístolas contemporâneas que deveriam ser lidas nas Igrejas (1 Ts 5.27). Adicione a esta lista inúmeras doxologias (Gl 1.5) e bênçãos (Gl 6.18), [...] o maranata (1 Co 11.26, 16.22) e até mesmo fórmulas litúrgicas futuras a serem repetidas e cantadas pelos santos e anjos no céu (Ap 4, 5, 7, 11, 15, 16, 19 e 22) (DeYOUNG, KLUCK, 2010, p. 12)

Muito embora a eclesiologia, da Igreja primitiva à oriental, jamais tenha figurado entre os temas mais relevantes no desenvolvimento teológico, o início do século XIV testemunhou um gradativo interesse nos problemas da Igreja. Se obras como "Suma Teológica" e "Sentenças", escritas, respectivamente, por Tomás de Aquino e Pedro Lombardo, não reservaram debate ao conjunto de questões sobre a Igreja, Tiago de Viterbo, naquele que seria o primeiro tratado acerca da Igreja, afirmaria que "a confissão de fé está principalmente preocupada com dois assuntos, Cristo como Rei e o cabeça e a Igreja como o Reino e o corpo dele" (PELIKAN, 2016, p. 131).

Dado seu irrompimento no século XVI, a Reforma Protestante, embora divergindo em termos fundamentais do Catolicismo Romano, jamais contrapôs-se a importância da Igreja institucional. Para Lutero e os reformadores, a ministração autêntica da Palavra, junto à confissão e conduta dos crentes é a marca distintiva da Igreja terrena.

Não obstante os reformadores concordassem com a assertiva romana de que não há salvação fora da Igreja, percebe-se neles um conceito completamente distinto de Igreja. Não mais aquela instituição historicamente ligada aos apóstolos, mas, agora, "os santos crentes e ovelhas que ouvem a voz de seu Pastor". Afinal, não somos salvos por fazer parte de uma Igreja, mas somos parte da Igreja por sermos salvos.

Calvino, o reformador de Genebra, frequentemente referia-se à Igreja como a "mãe dos crentes", capaz de nos dar o nascimento e nutrir-nos pela pregação do Evangelho e administração dos sacramentos. Em sua obra "Instituição da Religião Cristã" reitera que aquele que se recusa a ser filho da Igreja em vão deseja ter a Deus como seu Pai, uma vez que é somente através do ministério da Igreja que Deus gera filhos para si e os educa até que atravessem a adolescência e alcancem a maturidade (CALVINO, 2002, p. 52). 
Notoriamente atacada pelo movimento dos desigrejados, a Igreja como instituição é utopia quando despida de organização e governo. Embora Cristo se reservasse o direito de exercer seus ofícios livre das realizações humanas, aprouve a ele usar seus serviços no exercício de sua soberania e pregação do Evangelho.

Isso é necessário - por uma necessidade hipotética, visto que, sobre a terra, a Igreja está em processo de tornar-se. No céu, todo ofício eclesiástico e todos os meios da graça deixarão de funcionar porque o Reino de Deus será completo e Deus será tudo em todos. Mas na terra é diferente. Como ajuntamento dos crentes, a Igreja é usada por Cristo como um instrumento para trazer pessoas ao seu aprisco. Por meio dela, Cristo administra seu ofício mediatorial no meio do mundo (BAVINCK, 2012, p. 333).

À vista disso, a institucionalização dos crentes é um acontecimento natural no chamamento de Deus. Por semelhante modo ao templo de Salomão e ao sábado que, em essência, não foram criados como fim, mas um meio, a instituição não liquida a essência, mas somente a representa (CAMPOS, 2017, p. 143). Logo, o problema não reside na forma, mas no homem que valoriza a causa além do fundamento, sua estrutura em detrimento da importância e necessidade.

Logo, percebe-se que entre a visão de Igreja como organismo e como instituição não há rivalidade, mas uma abordagem unilateral que revela conjunção, interação e influência mútua. Assim, do mesmo modo que a criação jamais permaneceu sem governo, uma vez que Adão fora criado como cabeça da humanidade, a Igreja jamais existiu ausente da figura de governo, seja no campo invisível, tendo Cristo como cabeça, ou visível, no qual sempre possuiu uma forma de governo (BAVINCK, 2012, p. 336).

\section{Conclusão}

Crítico contumaz da metafísica, Nietzsche permitiu uma ressignificação e reinterpretação da religiosidade ausente de um absoluto, caracterizada, assim, pela subjetividade e experiência religiosa. Embora as consequências de seu deicídio não tenham produzido, em síntese, um ateísmo no seio da cristandade, seu pensamento fomentou a noção de libertação dos dogmas. Desse modo, toda crença deveria, impreterivelmente, ser chamada à julgamento a fim de comprovar sua validade na contemporaneidade. 
Desprendido de pertencimento institucional e em seu individualismo contemporâneo, o homem pós-moderno flerta com uma religião que lhe garante autonomia e liberdade, sendo interiorizada como um meio que lhe concede sentido à vida. O que se percebe é a proposta de um novo caminho fundamentado na noção de ruptura, descontinuidade e abandono de antigos comportamentos que passa a combater toda e qualquer noção de fixidez e dogmatismo.

Ainda que a crítica moderna não seja de todo equivocada, reavaliar sua conduta num mundo corrompido deve ser a grande responsabilidade de todo organismo que objetiva ser sal da terra e luz do mundo (Mt 5,13-14). Como afirmado pelo teólogo holandês Gisbertus Voetius, “Ecclesia reformata et semper reformanda est", expressão que pode ser traduzida por "Igreja reformada está sempre se reformando".

Contrariando a desqualificação leviana dos que defendem um cristianismo desprendido de forma e estrutura, importa empenhar-nos na busca por um modelo de eclesiologia incapaz de limitar a ação do Espírito, bem como de nos envolver numa casca morta que produza um Evangelho espiritualmente inócuo ao mundo. Logo, cabe ao homem pós-Nietzsche repensar seu modo de construir cultura. Essa é a Igreja que vive no mundo, avança em sua causa e reforma suas estruturas a fim de que possa sempre viver para a glória de Deus.

\section{Referências}

AZEVEDO, P. R. Teologia fundamental 1. Campinas: Ecclesiae, 2011.

BANNERMAN, J. A Igreja de Cristo: Um tratado sobre a natureza, poderes, ordenanças, disciplina e governo da Igreja cristã. Recife: Os puritanos, 2014.

BARCALA, M. Cristianismo arreligioso. São Paulo: Arte Editorial, 2010.

BAUMAN, Z. Modernidade e ambivalência. Rio de Janeiro: Zahar, 1999.

BAVINCK, H. Dogmática reformada: Espírito Santo, Igreja e nova criação. São Paulo: Cultura Cristã, 2012.

BOMILCAR, N. Os sem-lgreja. Buscando caminhos de esperança na experiência comunitária. São Paulo: Mundo Cristão, 2012.

BONHOEFFER, D. Tentação. São Leopoldo: Sinodal, 2003.

BRAY, G. Igreja. Um relato teológico e histórico. São Paulo: Vida Nova, 2017. 
BUREAU DE PESQUISA E ESTATÍSTICA CRISTÃ. Censo 2010: Em meio ao crescimento evangélico, há grande retração das denominações protestantes históricas. Disponível em: <http://www.genizahvirtual.com/2012/07/censo-2010-em-meio-ao-crescimento.html>. Acesso em: 20 abr. 2017.

CALVINO, J. Instituição da religião cristã. São Paulo: Cultura Cristã, 2002. v. 2.

CAMPOS, I. Desigrejados: Teoria, história e contradições do niilismo eclesiástico. Rio de Janeiro: bvbooks, 2017.

COMPENHAUSEN, H. V. Os Pais da Igreja: A Vida e a doutrina dos primeiros teólogos cristãos. Rio de Janeiro: CPAD, 2010.

COSTA, J. Sociologia da religião: uma breve introdução. Aparecida: Editora Santuário, 2009.

DEBRAY, R. O fogo Sagrado: funções do religioso. Porto: Ambar, 2005.

DELUMEAU, J. Mil anos de felicidade: uma história do paraíso. São Paulo: Companhia das Letras , 1997.

DeYOUNG, K; KLUCK, T. Por que amamos a Igreja. São Paulo: Mundo Cristão, 2010.

DREHER, M. História da Igreja. vol. 1-4. São Leopoldo: Sinodal, 1996.

FERREIRA, F.; MYATT, A. Teologia sistemática. São Paulo: Vida Nova, 2007.

GONZÁLEZ, J. História ilustrada do Cristianismo. São Paulo: Vida Nova, 2011.

HEIDEGGER, M. A sentença nietzschiana "Deus está morto". Natureza Humana, São Paulo, v. 5, n. 2, p. 471-526, 2003.

INSTITUTO BRASILEIRO DE GEOGRAFIA E ESTATÍSTICA. Censo demográfico 2010: características gerais da população, religião e pessoas com deficiência. Disponível em: <www.ibge.gov.br>. Acesso em: 24 abr. 2017.

KIVITZ, E. R. Outra espiritualidade. Fé, graça e resistência. São Paulo: Mundo Cristão, 2006.

LEFRANC, J. Compreender Nietzsche. Petrópolis: Vozes, 2005.

LIMA, S. H. B. A crítica de Nietzsche à religião cristã. 2015. 115 f. Dissertação (Mestrado em Ciências da Religião) — Universidade Católica de Pernambuco, Recife, 2015.

LATOURETTE, K. S. Uma história do cristianismo. São Paulo: Hagnos, 2007.

LOPES, A. N. Os desigrejados. 2010. Disponível em: <http://www.temporamores.blogspot.com.br>. Acesso em: 23 mai. 2017.

MATOS, A. S. A caminhada cristã na história: a Bíblia, a igreja e a sociedade ontem e hoje. Viçosa: Ultimato, 2005.

MILLER, A. Os irmãos. Diadema: Depósito de Literatura Cristã, 2005. 
MONDIN, B. Os grandes teólogos do século vinte. São Paulo: Edições Paulinas, 1980. v. 2.

MULLIN, A. Nietzsche's free-spirit. Journal of the History of Philosophy, Baltimore, v.38, n.3, p.383-405, 2000.

NIETZSCHE, F. O anticristo. Rio de Janeiro: Nova Fronteira, 2016a.

NIETZSCHE, F. A gaia ciência. São Paulo: Martin Claret, 2016b.

NIETZSCHE, F. Além do bem e do mal. São Paulo: Martin Claret, 2015.

NIETZSCHE, F. Humano, demasiado humano. São Paulo: Companhia de Bolso, 2008.

OLSON, R. E. História da teologia cristã: 2000 anos de tradição e reforma. São Paulo: Vida, 2001.

PELIKAN, J. A tradição cristã: uma história do desenvolvimento da doutrina. A reforma da igreja e o dogma (1300-1700). São Paulo: Shedd Publicações, 2016.

PIERUCCI, A. F. "Bye bye, Brasil" - o declínio das religiões tradicionais no Censo 2004. Revista de Estudos Avançados, São Paulo, v.18, n.52, p.17-28, 2004.

PORTELLA, R. A religião na sociedade secularizada: urdindo as tramas de um debate. Numen: revista de estudos e pesquisa da religião, Juiz de Fora, v. 11, n. 1 e 2, p. 33-53, 2008.

ROLOFF, J. A Igreja no Novo Testamento. São Leopoldo: Sinodal, 2005.

SOUZA, M. L. R. O réquiem divino: a morte de Deus e A gaia ciência de Nietzsche. 2007. 174 f. Dissertação (Mestrado em Ciências da Religião) - Pontifícia Universidade Católica de São Paulo, São Paulo, 2007.

STRATHERN, P. Nietzsche em 90 minutos. Rio de Janeiro: Jorge Zahar, 1997.

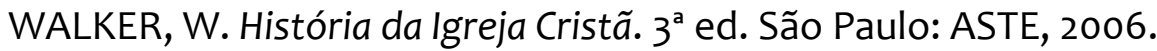

ZILLES, U. A crítica da religião na modernidade. Interações, Belo Horizonte, v. 3, n. 4, p. 3754, 2008. 